\title{
Physical, mechanical and natural durability properties of wood from reforestation Pinus halepensis Mill. in the Mediterranean Basin
}

\author{
Mohamed Tahar ELAIEB ${ }^{1}$ \\ Foued SHEL ${ }^{2}$ \\ Sabri ELOUELLANI ${ }^{3}$ \\ Tarik JANAH ${ }^{4}$ \\ Mohamed RAHOUTI ${ }^{4}$ \\ Marie-France THÉVENON ${ }^{5}$ \\ Kévin CANDelieR ${ }^{5}$ \\ ${ }^{1}$ Institut national de recherches en génie \\ rural, eaux et forêts (INRGREF) \\ LGVRF \\ BP 10 \\ 2080 Ariana \\ Tunisia
}

${ }^{2}$ Arrondissement des forêts, Sousse Rue d'Alger 4029 Sousse Tunisia

${ }^{3}$ Arrondissement des forêts, Nabeul Rue Mongi bali 8019 Nabeul

Tunisia

${ }^{4}$ Université Mohammed V Faculté des Sciences Laboratoire de Botanique Département de Biologie Avenue Ibn Battouta BP 1014, 10000 Rabat Maroc

${ }^{5}$ CIRAD

Unité de Recherches BioWooEB

TA B $114 / 16$

34398 Montpellier

France

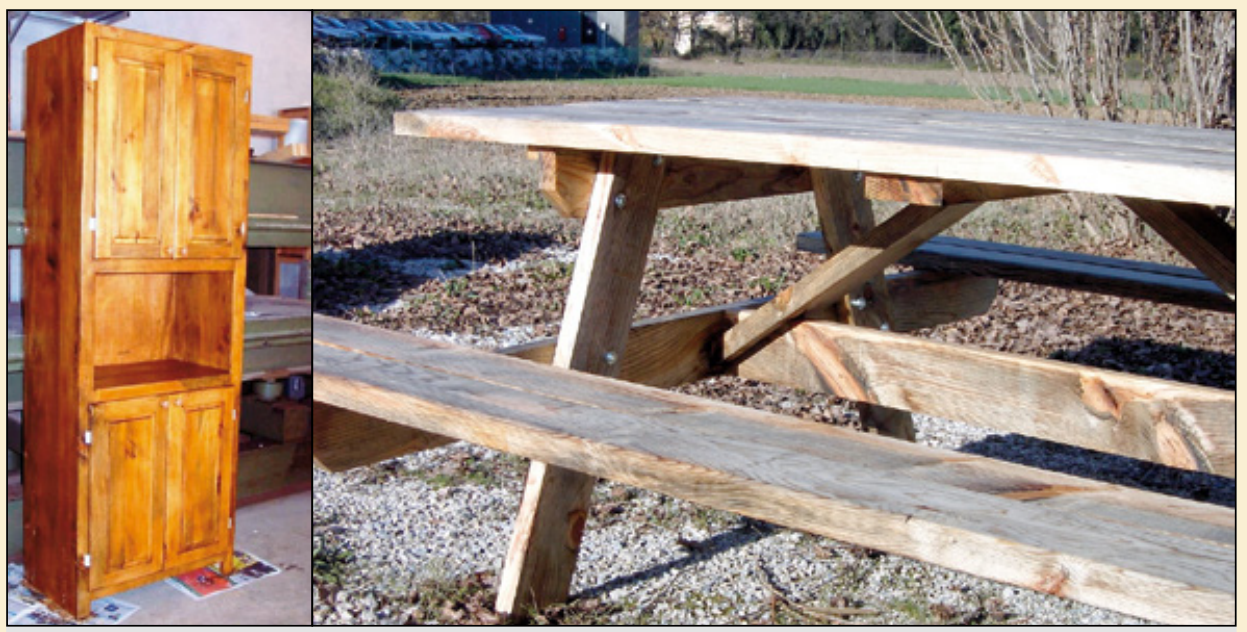

Photo 1.

Illustrations of Aleppo Pine wood furniture (manufactured by CIRAD, (C Claude Daigremont). Photo C. Daigremont. 


\section{RÉSUMÉ}

\section{PROPRIÉTÉS PHYSIQUES, MÉCANIQUES ET DE DURABILITÉ NATURELLE DU BOIS DE PLANTATION DE PINUS HALEPENSIS Mill. DANS LE BASSIN MÉDITERRANÉEN}

Le pin d'Alep Pinus halepensis Mill. fut introduit dans les régions à climat méditerranéen comme arbre d'ornement, et se trouve souvent aujourd'hui dans les jardins et espaces verts. Les peuplements de pin d'Alep (Pinus halepensis Mill.) recouvrent aujourd'hui quelque 2500000 ha dans le pourtour méditerranéen, généralement à faible altitude (moins de $500 \mathrm{~m}$ ) et sur les côtes. L'essence s'est naturalisée en dehors des villes du Maghreb à tel point qu'elle y est classée aujourd'hui comme espèce invasive. En raison de ses dimensions (plus de $15 \mathrm{~m}$ de hauteur et $30 \mathrm{~cm}$ de diamètre), Pinus halepensis pourrait représenter une ressource de bois d'œuvre intéressante en Tunisie. La présente étude s'est attachée à évaluer la résistance à la pourriture et les propriétés physiques et mécaniques des pins d'Alep de plantation dans le bassin méditerranéen. Les échantillons de bois de Pinus halepensis étudiés ont été prélevés en Tunisie pour les tests de caractérisation physique et mécanique (six provenances) et au Maroc pour les tests de résistance à la pourriture et aux termites. Des tests ont permis de déterminer la densité et la rétraction ainsi que la résistance à la pourriture. Les premiers résultats indiquent que le bois de Pinus halepensis de Tunisie possède une grande stabilité dimensionnelle et une résistance élevée à la compression. Cependant, la résistance à la flexion est assez faible quelle que soit la provenance. Le module de résistance en flexion est plus faible que pour les autres résineux en Tunisie. Enfin, l'aubier du pin d'Alep est peu résistant aux maladies fongiques et aux termites. Cette essence pourrait s'avérer intéressante comme bois d'œuvre ou pour l'ébénisterie, à condition d'y appliquer un traitement de protection préalable à son emploi.

Mots-clés : Pinus halepensis, pin d'Alep, résistance au pourrissement, zones de reforestation au Maghreb, propriétés mécaniques, propriétés physiques, densité des peuplements.

\section{ABSTRACT}

\section{PHYSICAL, MECHANICAL AND NATURAL DURABILITY PROPERTIES OF WOOD FROM REFORESTATION PINUS HALEPENSIS MILL. IN THE MEDITERRANEAN BASIN}

Pinus halepensis Mill. was introduced into regions with a Mediterranean climate as an ornamental tree, and is now often found in parks and gardens. At present, Aleppo pine (Pinus halepensis Mill.) forests cover approximately 2,500,000 ha in the Mediterranean Basin, mostly at low altitudes (less than $500 \mathrm{~m}$ ) and along the coast. It has become naturalized outside cities in North Africa to the extent that it is now listed as an invasive species there. Because of its size (over $15 \mathrm{~m}$ in height and $30 \mathrm{~cm}$ in diameter), Pinus halepensis could be a good potential green resource for structural material in Tunisia. The focus of this study was to assess rot resistance and the physical and mechanical properties of reforestation Aleppo pine from the Mediterranean basin. The Pinus halepensis wood samples studied were collected from 6 tree provenances in Tunisia for physical and mechanical characterization and from Morocco for decay and termite resistance tests. Densities and shrinkage were determined and mechanical and rot resistance tests performed. Preliminary results showed that Tunisian Pinus halepensis wood has great dimensional stability. Although the compressive strength of Pinus halepensis wood is high, its bending strength is rather low for each of the provenances. MOR in bending is lower than in other Tunisian softwood species. Finally, Pinus halepensis sapwood has low resistance to fungi and termites. This timber species could be valuable for furniture and/or as a building material provided that a wood preservation method is applied before it is used.

Keywords: Pinus halepensis, Aleppo Pine, rot resistance, Maghreb reforestation areas, mechanical properties, physical properties, tree stand density.

\section{RESUMEN}

\section{PROPIEDADES FÍSICAS, MECÁNICAS Y DE DURABILIDAD NATURAL DE LA MADERA DE REFORESTACIÓN DE PINUS HALEPENSIS Mill. EN LA CUENCA MEDITERRÁNEA}

El pino carrasco Pinus halepensis Mill. se introdujo en las regiones de clima mediterráneo como árbol ornamental y actualmente es frecuente en jardines y espacios verdes. En la actualidad los bosques de pino carrasco (Pinus halepensis Mill.) cubren unas 2500000 ha en el contorno mediterráneo, generalmente en bajas altitudes (menos de $500 \mathrm{~m}$ ) y en las costas. La especie se ha naturalizado tanto fuera de las ciudades del Magreb que ahora se la considera como especie invasora. Por sus dimensiones (más de $15 \mathrm{~m}$ de altura y $30 \mathrm{~cm}$ de diámetro), Pinus halepensis podría representar un interesante recurso en madera de construcción en Túnez. Este estudio se centró en evaluar la resistencia a la pudrición y las propiedades físicas y mecánicas de los pinos carrascos de repoblación en la cuenca mediterránea. Las muestras de madera de Pinus halepensis estudiadas se tomaron en Túnez para las pruebas de caracterización física y mecánica (6 procedencias) y en Marruecos para las pruebas de resistencia a la pudrición y a los isópteros. Las pruebas permitieron determinar la densidad y contracción, así como la resistencia a la pudrición. Los primeros resultados indican que la madera de Pinus halepensis de Túnez posee una gran estabilidad dimensional y una alta resistencia a la compresión. No obstante, su resistencia a la flexión es bastante baja en todas las procedencias. El módulo de resistencia a flexión es menor que en las demás resinosas de Túnez. Por último, la albura del pino carrasco es poco resistente a hongos y a termitas. Esta especie podría resultar interesante como madera de construcción o para muebles, siempre y cuando se aplique un tratamiento protector antes de su uso

Palabras clave: Pinus halepensis, pino carrasco, resistencia a la pudrición, áreas de repoblación en el Magreb, propiedades mecánicas, propiedades físicas, densidad de rodal. 


\section{Introduction}

Aleppo Pine (Pinus halepensis Mill.) is a tree species spread all around the Mediterranean basin including the islands. Its continental range extends from northern Africa (Morocco, Algeria, Tunisia and Libya) and Middle East (Syria, Lebanon, Jordan, Palestina and Turkey), up to southern Mediterranean Europe (eastern Greece, Croatia, southern Italy, southern France and eastern Spain). This coniferous wood species covers about 2.5 million hectares in the Mediterranean basin, mostly at low elevations (below $500 \mathrm{~m}$ ) and along the coastline (Mitsopopoulos and Dimitrikopopoulos, 2007).

In Tunisia, the Aleppo Pine forests cover 361,250 ha, representing more than $53 \%$ of Tunisian woodlands (DGF, 2010). About two-thirds of these forests are native stands which are occurring in semi-arid areas from northern to central Tunisia. The third remainder is made up of evenaged plantations which were implemented after the 1960's (Garchi and Ben Mansoura, 1999). In terms of reforestation in Morocco, artificial forests where Aleppo Pine is the most used tree (Boulli et al., 2001) represent about 156,670 ha (Aafi, 2007). In Algeria, Aleppo Pine, considered the most important and dominant local forest species, covers a surface estimated at more than 800,000 ha (Haddad et al., 2009; Ricard and Oliva, 1995). This typical Mediterranean wood species, easily adaptable to various eco-climatic conditions, which grants it the privilege of being the most often used tree species in the Maghreb countries' reforestation programs. The wood quantity which could be mobilized is considerable, as part of logging or thinning operations and could satisfy several industrial uses (timber wood, decking industry, paper industry...) (Haddad et al., 2009). Nevertheless, its industrial utilization rate remains low, compared to the availability of wood.

Aleppo Pine is a xerophytic and heliophilous wood species with little and irregular annual growth. The biggest trees may reach $50 \mathrm{~cm}$ of diameter and $20 \mathrm{~m}$ height but they usually do not get over $40 \mathrm{~cm}$ of diameter and $15 \mathrm{~m}$ height. The stem it is not very straight, large branches are common, which sometimes weakens the wood quality. Around the Mediterranean basin, Aleppo Pine tree has an average growth of $2.4 \mathrm{~m}^{3} / \mathrm{ha} /$ year (Gracia et al., 2004). Natural discontinuous bands and large geographical distributions of Aleppo Pine were recorded in the Mediterranean region (figure 1 ).

Most studies on the Aleppo Pine in Tunisia estimate its productivity lower than $1.5 \mathrm{~m}^{3} / \mathrm{ha} /$ year in the best stations, while in France it can reach $4 \mathrm{~m}^{3} / \mathrm{ha} /$ year (Snan et al., 1992).
In Morocco and Algeria, Aleppo Pine average growth varies from 0.72 to $1.725 \mathrm{~m}^{3} / \mathrm{ha}$ /year and from 1.2 to $1.5 \mathrm{~m}^{3}$ / ha/year, respectively (Belghazi et al., 2000). These variations could be explained by the fact that Aleppo Pine requires a minimum annual rainfall of $400 \mathrm{~mm}$, and preferably $450 \mathrm{~mm}$ or more for reasonable growth rates. It grows better when there is seasonal ground water access, run-on water or irrigation and prefers deep well-structured soils or soils prepared by deep ripping and mounding (Crammond, 1999).

These reforestation Aleppo Pines are now reaching their maturity and it is necessary to promote their use in an optimal way to contribute to the economy sustainability of these countries. So far, the Aleppo Pine is currently mainly being used in furniture market in Mediterranean European regions (photo 1), and by the packaging industry for producing pallets, mostly in Spain. However, traditionally round trunks were used as beams in isolated houses located nearby the forests, especially in the Mediterranean coast where it is the most abundant tree (Correal-Mòdol and Vilches Casals, 2012). Haddad et al. (2006) showed that Aleppo Pine wood could be also a good fibrous source for the Algerian papermaking industry and as a mean for a rational upgrading of the wood resources available by Aleppo Pine reforestation.

However, few studies have been conducted to characterize the Aleppo Pine wood properties, such as chemical composition, mechanical characteristics, decay resistance, etc. It appears nonetheless that technological properties of Aleppo Pine wood vary widely according to various external factors, including the age of the trees and the growth conditions (Malkh, 2001; Dilem, 1992; Thibaut et al., 1992). These last studies highlighted those Aleppo Pine wood

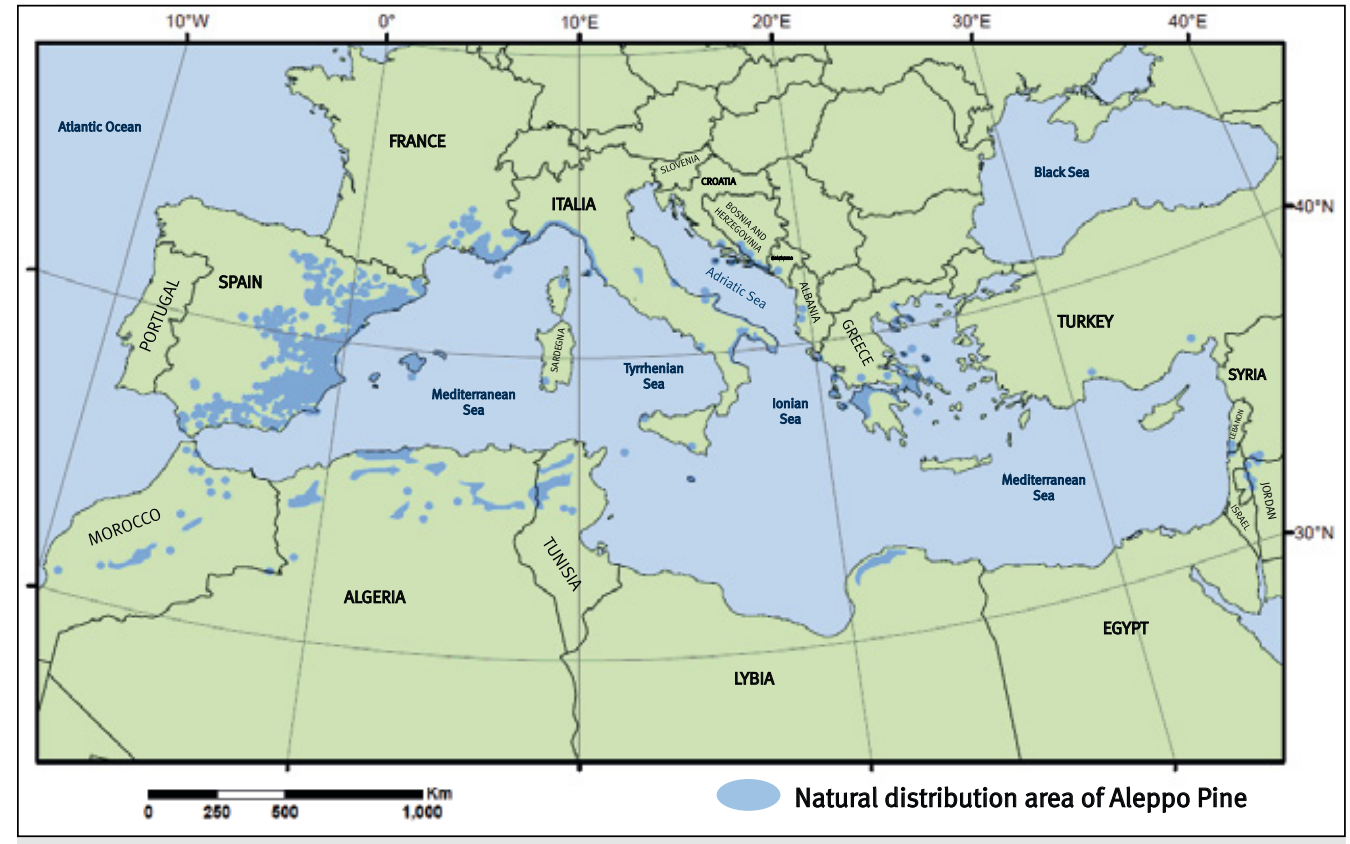

Figure 1.

Aleppo Pine forests distribution in the Mediterranean region (EUROFORGEN 2009). 
Table I.

Comparison of average intrinsic properties Aleppo Pine woods from different countries in the Mediterrean area.

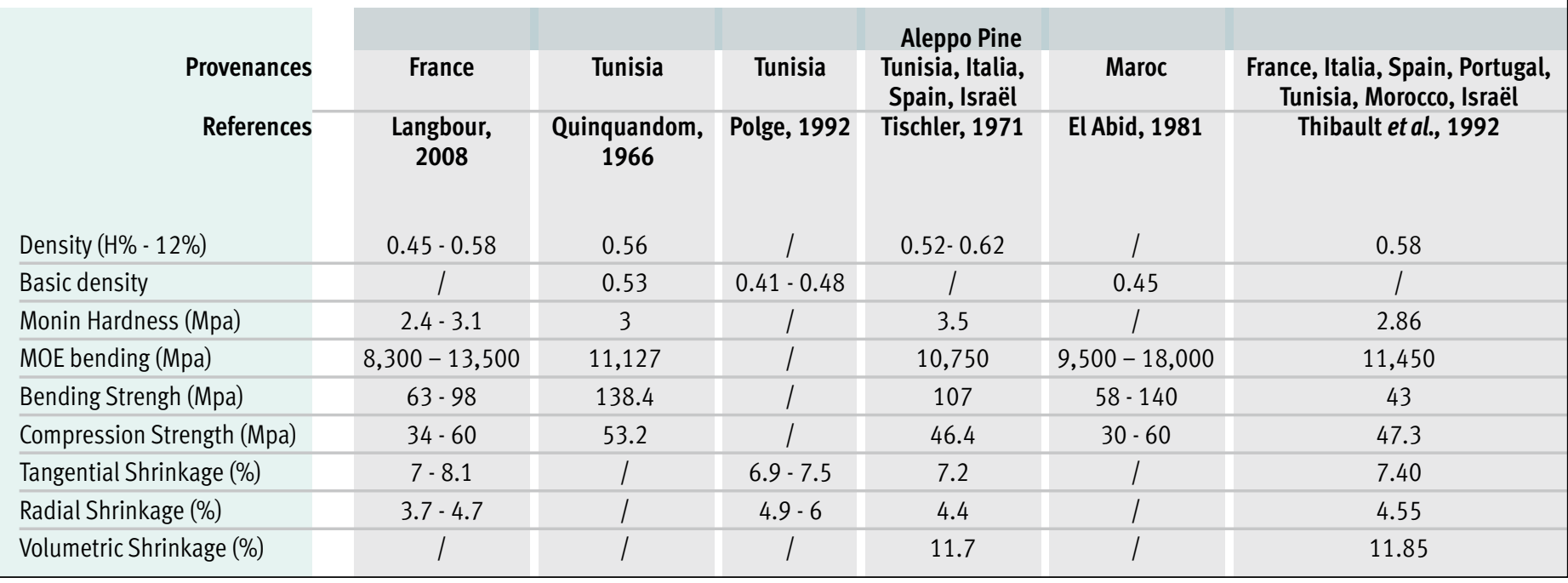

physical and mechanical properties were similar to those of the Scots Pine, Douglas fir and Spruce (Gérard et al., 2004). According to previous studies whose the results are presented in table I, Aleppo Pine wood species could be classified as light (Density $=0.45-0.62$ ), soft (Monnin hardness $=$ 2.4 - 3.5) and medium mechanical strength wood (Bending $\mathrm{MOE}=8300-18000 \mathrm{MPa}$, Bending MOR $=43-140 \mathrm{MPa}$ ). These last properties remain highly variable depending on the geographical distribution of the tree populations mainly due to the tree growing conditions (ex: fast growing trees have lower densities), which requires the implementation of local studies towards a better understanding of the wooden material characteristics (Langbour et al., 2008). More physical properties of Aleppo Pine woods from different countries of Mediterranean area are illustrated in table I.

Very few studies have been conducted on the determination of the natural decay resistance of Aleppo Pine wood and it is not even mentioned in EN 350 (2016). However, Montibus (2015) showed that Aleppo Pine heartwood tested against Poria placenta and Coniophora puteana (according to XP CEN/TS 15083-1, 2006) is slightly durable (durability class 4$)$. However, a closer look to this classification, based on the median mass loss of the samples, shows that $30 \%$ and $50 \%$ of them are allocated to the durability class 5 (non-durable) towards Coniophora and Poria respectively. These results are consistent with data reported for other Pine wood species and listed in EN 350 (2016). Thus, the Maritime Pine has a durability class of "moderately to slightly" durable (classes 3-4) and Corsica Laricio Pine has a durability class of "slightly durable" (class 4) with a high level of variability. However, Aleppo Pine sapwood has an impregnability class-1 allowing it to be efficiently treated by the addition of wood preservative conferring to the wood material a durability up to class 1 (very durable), which allows it to be used in outdoor or wet conditions (Montibus, 2015).

Through several studies on the Tunisian woods thermal modification (Elaieb et al., 2014; Candelier et al.,
2015; Elaieb et al., 2015), Tunisian Aleppo Pine samples [25 $\times 10 \times 5 \mathrm{~mm}^{3}(\mathrm{~L} \times \mathrm{R} \times \mathrm{T})$ ] were submitted to screening decay resistance tests during 16 weeks, as virulence control samples, under different fungal attacks. Results showed that Aleppo Pine wood has a durability class-4 against Poria placenta $(M L \approx 25 \%)$ (Elaieb et al., 2015), Coriolus versicolor $(\mathrm{ML} \approx 24 \%)$, Gloeophyllum trabeum $(\mathrm{ML} \approx 22 \%)$ and Coniophora puteana $(M L \approx 23 \%)$ (Elaieb et al., 2014).

The goal of the study was to characterize the physical, mechanical properties and decay resistance to identify the potential valorization of the Aleppo Pine from Maghreb.

Considering that the Aleppo Pine is a significant resource in Maghreb area, this work has focused on two objectives: (i) the study about the physical and mechanical properties of Aleppo Pine wood from six provenances in Tunisia, (ii) the study on the natural decay and termite resistance of Aleppo Pine wood from Morocco.

\section{Materials and methods}

\section{Physical and mechanical characterization}

\section{Trees data selection}

To estimate the physical and mechanical properties of Tunisian reforestation Aleppo Pine, 6 Aleppo Pine provenances in Tunisia were investigated: Jebel Abderrahmane, Sodga, M'guila, Sakiet, Selloum, Dernaia.

Twelve Aleppo Pine trees were collected in the arboretum of the region of Menzel Bouzelfa (36 $48^{\prime} 59^{\prime \prime} \mathrm{N}$; $\left.10^{\circ} 34^{\prime} 07^{\prime \prime} \mathrm{E}\right)$. Two trees for each provenance were selected. According to Oger and Leclercq (1997), sampling applied to the determination of physical and mechanical properties is optimal when it is performed on a tree quantity comprised from one to five, provided that selected trees are healthy, free from defects and alteration, and have an almost perfectly straight. The studied trees were selected according to these last parameters and were classified in three different 
Table II.

Characteristics of six provenance sites in Tunisia and Aleppo Pine trees sampling.

\begin{tabular}{|c|c|c|c|c|c|c|c|c|c|c|}
\hline \multirow{2}{*}{$\begin{array}{l}\text { Provenance sites } \\
\text { in Tunisia }\end{array}$} & \multirow[t]{2}{*}{ Ref. } & \multirow[b]{2}{*}{$\begin{array}{l}\text { Lat. } \\
\text { (deg) }\end{array}$} & \multirow[b]{2}{*}{$\begin{array}{l}\text { Long. } \\
\text { (deg) }\end{array}$} & \multicolumn{3}{|c|}{ Site conditions* } & \multirow[b]{2}{*}{$\begin{array}{l}\text { Stand density } \\
\text { (Trees/ha) }\end{array}$} & \multirow{2}{*}{$\begin{array}{c}\text { Tree } \\
\text { quality** }\end{array}$} & \multicolumn{2}{|c|}{ Tree properties } \\
\hline & & & & $\begin{array}{l}\text { Alt. } \\
\text { (m) }\end{array}$ & $\begin{array}{l}\text { Plu. } \\
\text { (mm) }\end{array}$ & Soil & & & Diameter (m) & Size $(\mathrm{m})$ \\
\hline Jebel Abderrahmane (K) & $\begin{array}{l}\mathrm{K} 1 \\
\mathrm{~K} 2\end{array}$ & $36^{\circ} 42^{\prime}$ & $10^{\circ} 40^{\prime}$ & 200 & 550 & $\mathrm{~L}$ & $\begin{array}{l}312.50 \\
308.64\end{array}$ & 1 & $\begin{array}{l}0.16 \\
0.16\end{array}$ & $\begin{array}{c}11 \\
10.5\end{array}$ \\
\hline Sodga (W) & $\begin{array}{l}\text { W1 } \\
\text { W2 }\end{array}$ & $36^{\circ} 02^{\prime}$ & $9^{\circ} 35^{\prime}$ & 730 & 645 & L & $\begin{array}{l}277.77 \\
297.79\end{array}$ & 1 & $\begin{array}{l}0.16 \\
0.16\end{array}$ & $\begin{array}{c}10.7 \\
9.5\end{array}$ \\
\hline M’guila (AH) & $\begin{array}{l}\mathrm{AH} 1 \\
\mathrm{AH} 2\end{array}$ & $35^{\circ} 20^{\prime}$ & $9^{\circ} 12^{\prime}$ & 800 & 300 & L & $\begin{array}{l}151.50 \\
294.11\end{array}$ & 2 & $\begin{array}{l}0.15 \\
0.22\end{array}$ & $\begin{array}{l}10.5 \\
11.6\end{array}$ \\
\hline Sakiet $(\mathrm{H})$ & $\begin{array}{l}\mathrm{H} 1 \\
\mathrm{H} 2\end{array}$ & $36^{\circ} 15^{\prime}$ & $8^{\circ} 25^{\prime}$ & 700 & 700 & $M-L$ & $\begin{array}{l}286.36 \\
500.00\end{array}$ & 2 & $\begin{array}{l}0.15 \\
0.19\end{array}$ & $\begin{array}{l}11.7 \\
11.3\end{array}$ \\
\hline Selloum (AG) & $\begin{array}{l}A G 1 \\
A G 2\end{array}$ & $35^{\circ} 05^{\prime}$ & $8^{\circ} 40^{\prime}$ & 900 & 400 & $M-L$ & $\begin{array}{l}202.42 \\
151.33\end{array}$ & 3 & $\begin{array}{c}0.165 \\
0.18\end{array}$ & $\begin{array}{c}10 \\
10.3\end{array}$ \\
\hline Dernaia (V) & $\begin{array}{l}\text { V1 } \\
\text { V2 }\end{array}$ & $35^{\circ} 07^{\prime}$ & $8^{\circ} 30^{\prime}$ & 1,100 & 275 & S-L & $\begin{array}{l}157.13 \\
212.44\end{array}$ & 3 & $\begin{array}{l}0.15 \\
0.18\end{array}$ & $\begin{array}{c}10 \\
10.2\end{array}$ \\
\hline
\end{tabular}

classes (table II) according to their diameter, size and shape (Khouja et al., 2003). The methodology and the results used to determine the Aleppo Pine tree classes are detailed in a previous study by Sghaier and Khouja (2009).

\section{Physical properties}

Wood samples used for the physical and mechanical characterizations do not differentiate the sapwood and the heartwood for selected trees. Wood samples for physical and mechanical tests were randomly chosen in the log (figure 2), in order to observe the high results variability relating to the radial variation generally observed in such characterizations. However, intra-tree variations in wood properties according to the radial position are not discussed in this study. An overview of sampling for the physical and mechanical tests performed on the different trees issued from various Aleppo Pine provenances is shown on figure 2.

\section{Densities and shrinkages}

To perform physical and mechanical tests, a wooden disk $50 \mathrm{~mm}$ in thickness was cut at $1.40 \mathrm{~m}$ from the ground for each selected tree. To obtain a representative sampling of the exploitable Aleppo Pine wood resource as lumber wood, extreme cases such as excessively knotty trees or the presence of reaction wood or slope grain were discarded (ISO 4471, 1982). From each disk, 12 samples of $3 \mathrm{~cm}$ width from bark to bark were cut. These samples were then cut into strip $2 \mathrm{~cm}$ thick. Basic density (Db), Air-dry density (after conditioning at $20 \pm 2{ }^{\circ} \mathrm{C}$ and $65 \pm 5 \% \mathrm{RH}$ ) and Oven-dry (after drying at $103 \pm 2^{\circ} \mathrm{C}$ ) density $\left(\mathrm{D}_{\mathrm{m} 12}, \mathrm{D}_{\mathrm{mo}}\right)$ (ISO $13061-2,2014)$, shrinkage $(\beta)$ [tangential $(\beta t)$, radial $(\beta r)$, longitudinal $(\beta I)$ and volumetric $(\beta v)$ ] (ISO 4469, 1981) of the wood samples were determined using 12 wood specimens per tree of $20 \times 20 \times 10 \mathrm{~mm}$ (along the grain). The Transverse Anisotropy Ratio for Shrinkage (TARS) ( $\beta \mathrm{t} / \mathrm{\beta r}$ ) was the ratio between tangential and radial shrinkage. The densities were determined by the gravimetric method (Haygreen and Bowyer, 1996).

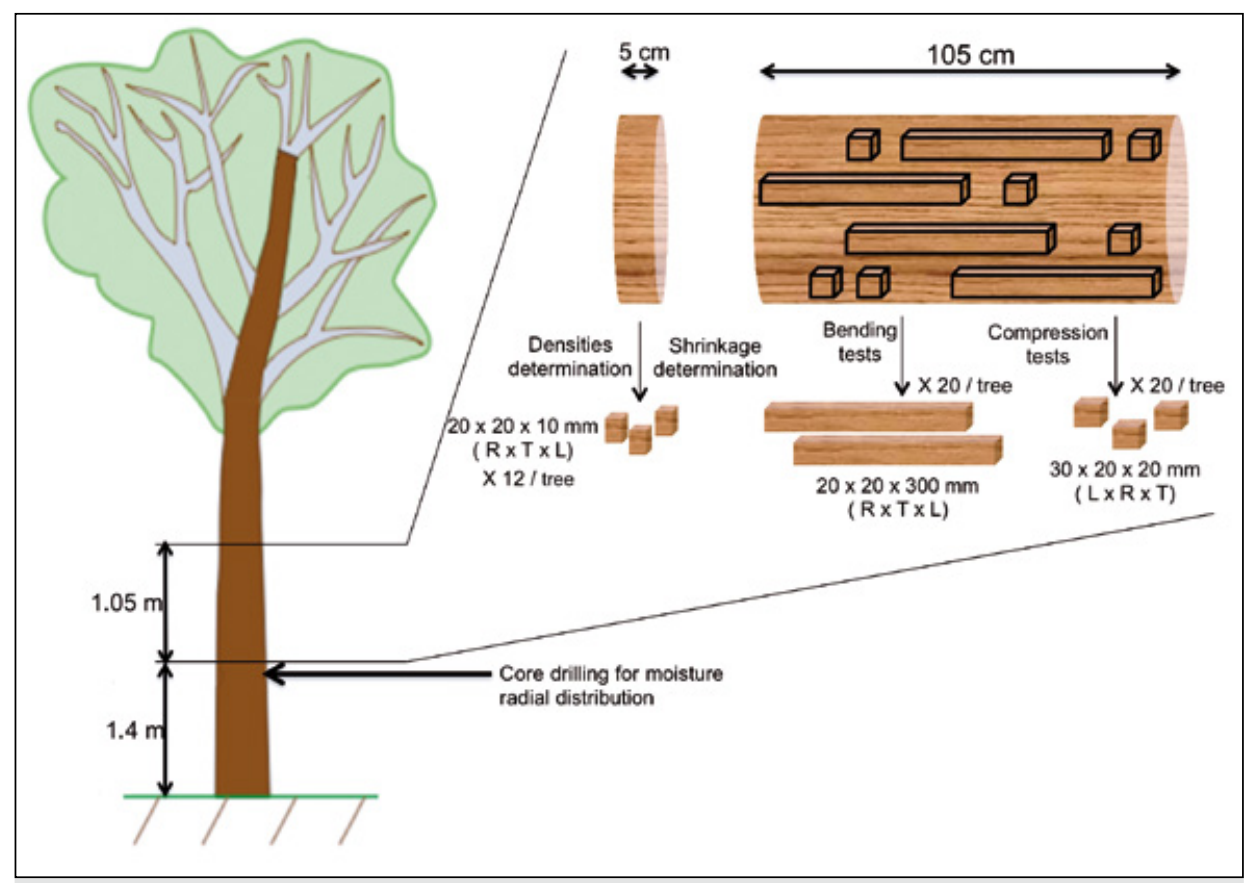

Figure 2.

Overview of wood samples selection for the physical and mechanical analyses. 
$D_{b}=\frac{m_{0}}{V_{h}}(1) ; D_{m 0}=\frac{m_{0}}{V_{0}}(2) ; D_{m 12}=\frac{m_{12}}{V_{12}}(3)$

Where:

$\mathrm{m}_{0}=$ oven-dried weight of the sample (g),

$\mathrm{m}_{12}=$ air-dried weight of the sample $(\mathrm{g})$,

$D_{b}=$ basic density of wood $\left(\mathrm{g} \cdot \mathrm{cm}^{-3}\right)$,

$D_{m 0}=$ oven-dried density of wood $\left(\mathrm{g} . \mathrm{cm}^{-3}\right)$,

$D_{m 12}=$ the Air-dried density of wood $\left(\mathrm{g} \cdot \mathrm{cm}^{-3}\right)$,

$\mathrm{V}_{\mathrm{h}}=$ green volume of the specimen $\left(\mathrm{cm}^{3}\right)$,

$\mathrm{V}_{0}=$ oven-dried volume of the sample $\left(\mathrm{cm}^{3}\right)$,

$\mathrm{V}_{12}=$ air-dried volume of wood sample $\left(\mathrm{cm}^{3}\right)$.

Volumetric shrinkage was measured by the following equation (4):

$\beta_{v}=\frac{\left(V_{h}-V_{0}\right)}{V_{h}} \times 100(4)$

Similar operations were used to determine tangential $(\beta \mathrm{t})$, radial $(\beta \mathrm{r})$ and longitudinal $(\beta \mathrm{l})$ shrinkages, using dimensional variation of the respective orientation.

\section{Mechanical strength properties}

To perform mechanical resistance tests, three point bending (MOR) and compression tests were carried out for each of the selected wood tree samples, and results were compared. An INSTRON 4467 Universal Mechanical Test Machine was used for the measurements. Samples were conditioned in a climate-controlled room with $65 \pm 5 \%$ $\mathrm{RH}$ and at $20 \pm 2{ }^{\circ} \mathrm{C}$ for the time required to stabilize the samples weights.

\section{Bending test}

Three point static bending tests were carried out according to the EN 408 (2003). The sample size was $300 \times 20 \times 20 \mathrm{~mm}^{3}(\mathrm{~L} \times \mathrm{R} \times \mathrm{T})$. The moving head speed and span length were $0.09 \mathrm{~mm} . \mathrm{s}^{-1}$ and $260 \mathrm{~mm}$, respectively. The load deformation data obtained were analyzed to determine the modulus of rupture (MOR). The tests were replicated on 20 samples from each selected Aleppo Pine tree.

\section{Compression strength parallel to grain}

Compression tests were carried out according to the EN 408 (2003). Deviating from the standard, a reduced specimen size of $30 \times 20 \times 20 \mathrm{~mm}^{3}$ ( $\left.L \times R \times T\right)$ was used. The moving head speed was $0.09 \mathrm{~mm} . \mathrm{s}^{-1}$ to ensure wood sample rupture within 1.5 to 2 minutes. The load deformation data obtained were analyzed to determine the modulus of rupture (MOR). 20 specimens per selected tree were tested.

\section{Decay resistance tests}

\section{Woods sample selection}

For the Aleppo Pine decay resistance study, trees used for testing come from an experimental Aleppo Pine reforestation area located in the region of $\mathrm{El} \mathrm{Had}$
Brachwa in Morocco (3342'23.3'N; 6³7'25.0” W). Two Aleppo Pine trees of diameter $70 \mathrm{~cm}$ at $1.30 \mathrm{~m}$ from the ground were selected.

\section{Natural durability tests}

Aleppo Pine heartwood samples of $5 \times 2.5 \times 1.5 \mathrm{~cm}^{3}$ $(L \times R \times T)$ coming from both trees were tested to evaluate their resistance against fungal attack according to XP CEN/TS 15083-1 (2006). Decay resistance was determined for three brown rot fungi: Coniophora puteana (Schumacher ex Fries) Karsten, strain BAM Ebw., Poria placenta (Fries) Cooke sensu J. Eriksson, strain FPRL 280, and Gloeophyllum trabeum (Persoon ex Fries) Murrill, strain BAM Ebw. 109. For each fungus, 32 Aleppo Pine heartwood samples and 10 Scot Pine (Pinus sylvestris) sapwood virulence controls were tested. Sterile culture medium prepared from malt (40 g) and agar (20 g) in distilled water $(1 \mathrm{~L})$, was placed in a culture flask inoculated with a small piece of mycelium of a freshly grown pure culture and incubated for two weeks at $22^{\circ} \mathrm{C}$ and $70 \%$ relative humidity $(\mathrm{RH})$ to allow full colonization of the medium by the mycelium. All wood samples were sterilized twice by autoclave at $121^{\circ} \mathrm{C}$ for $20 \mathrm{~min}$. Incubation was carried out for 16 weeks at $22^{\circ} \mathrm{C}, 70 \% \mathrm{RH}$ in a dark climatic chamber. Once the fungal exposure was completed, the mycelium was removed and the specimens were weighed in order to evaluate their moisture content at the end of the fungal exposure. The specimens were then dried at $103^{\circ} \mathrm{C}$, and their final weight was recorded. The moisture content at the end of the test (data not shown) as well as the weight loss were determined. Weight loss (WL) was expressed as a percentage of the initial oven-dry weight of the wood sample according to the formula:

$\mathrm{WL}(\%)=\frac{\left(\mathrm{m}_{0}-\mathrm{m}_{\mathrm{f}}\right)}{\mathrm{m}_{0}} \times 100(5)$

Where:

$m_{\mathrm{f}}=$ final dry mass of wood samples after fungal exposure, $\mathrm{m}_{0}=$ initial dry mass of wood sample.

According to the calculated media, mass loss, wood samples were classified in Durabiliy class. Durability classes from the XP CEN/TS 15083-1 (2006) standard are exposed on table III.

Table III.

Durability rating scale according to XP CEN/TS 15083-1 (2006).

\begin{tabular}{|l|c|c|}
\hline Durability class & Description & Per cent loss in mass \\
\hline 1 & Very durable & $\leq 5$ \\
\hline 2 & Durable & $>5$ to $\leq 10$ \\
\hline 3 & Moderately durable & $>10$ to $\leq 15$ \\
\hline 4 & Slightly durable & $>15$ to $\leq 30$ \\
\hline 5 & Not durable & $>30$ \\
\hline
\end{tabular}




\section{Results}

\section{Termite resistance tests}

Termite resistance was evaluated using Reticulitermes flavipes (ex santonensis) termites using a non-choice test based on the guidelines of the European standard EN118 (2005) - in accordance with EN 350-1 (1994) with a wood sample size adaptation. Five Aleppo Pine heartwood samples, from both trees, of size $10 \times 4 \times 1 \mathrm{~cm}^{3}(\mathrm{~L} \times \mathrm{R} \times \mathrm{T})$ were exposed to the attack of 250 termite workers, two nymphs and two soldiers, for eight weeks at $27^{\circ} \mathrm{C}, 75 \% \mathrm{RH}$.

Four Scot Pine (Pinus sylvestris) sapwood samples were tested in the same manner as controls. At the end of the biological exposure, the survival rate of the termites was evaluated, and visual rating of sample degradations was performed according to the EN118 (2005).

\section{Statistical analysis}

Statistical analyses (one-way analysis of variance) using Fisher test and the JMP 10.0.2 program (SAS Institute Inc., Cary, NC, USA) have been performed. The effects of Aleppo Pine tree provenances on the wood densities, shrinkages and mechanical properties were evaluated using ANOVA and Duncan's comparison test. Such analysis allows to class results into several categories from "A" to " $E$ ". Systems which are not connected by the same letter are largely different at the $5 \%$ level.

In addition, physical and mechanical results were compared together and to Aleppo Pine growth conditions as stand density in the provenance section. An ANOVA analysis was used to examine the difference in average value of each property between any two of stands. Meanwhile, the average values of each stand density variable and wood properties were calculated to establish a correlation table using a built-in Microsoft Excel ${ }^{\mathrm{TM}}$ statistical tool.

\section{Statistical analysis}

To show the impact of Aleppo Pine tree provenances on physical and mechanical properties, the ANOVA and Duncan's tests have been performed using the results cited above. These statistical analysis results are illustrated by letters from A to E, in figures 3, 4 and 5. Systems which are not connected by the same letter are largely different at the $5 \%$ level.

In addition, all results of Tunisians Aleppo Pine tree characteristics and their respective wood physical properties are synthetized in table IV. The results from statistical analysis issued from these average values are presented in table $\mathrm{V}$ and table VI.

Table $V$ shows the coefficients of correlation between forestry conditions (stand density), physical properties (Wood basic density - Db, volumetric shrinkage - $\beta v$ ) and mechanical strengths (Bending and compression strength MOR) which were measured in this study.

Finally, a focus has been done on the relationships between the Aleppo Pine stand density, the tree characteristics and the physical and mechanical wood properties. The results on such effects of stand density on wood properties are illustrated in Table VI.

\section{Physical and mechanical characterization}

\section{Densities}

Air-dried Density $\left(D_{m 12}\right)$ is commonly used to compare different woods. Basic Density (Db), Oven-Dried Density $\left(D_{m 0}\right)$ and Air-dried Density $\left(D_{m 12}\right)$ have been measured on each wood sample. Average values of these different densities are presented in table III. The results did not provide

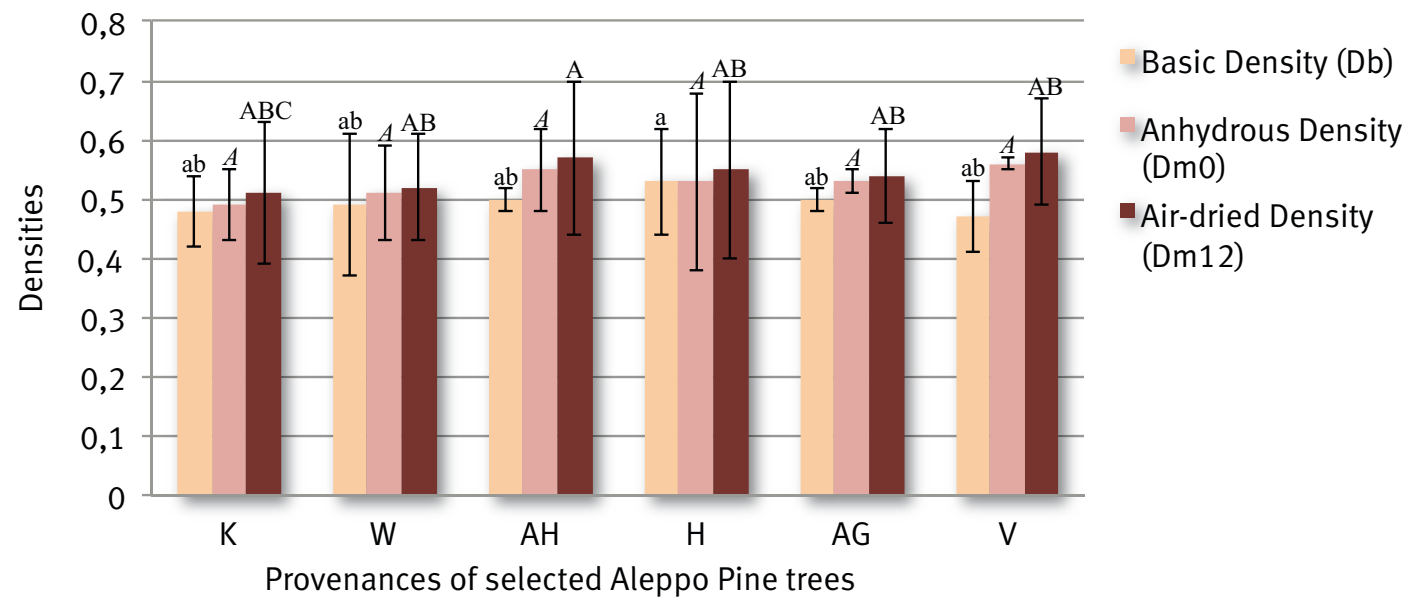

Figure 3.

Average and covariance values of basic, anhydrous and air-dried densities of Northern Tunisian Aleppo Pine woods. Provenances: Jbel Abderrahmane (K), Sodga (W), M'guila (AH), Sakiet (H), Selloum (AG), Dernaia (V). 


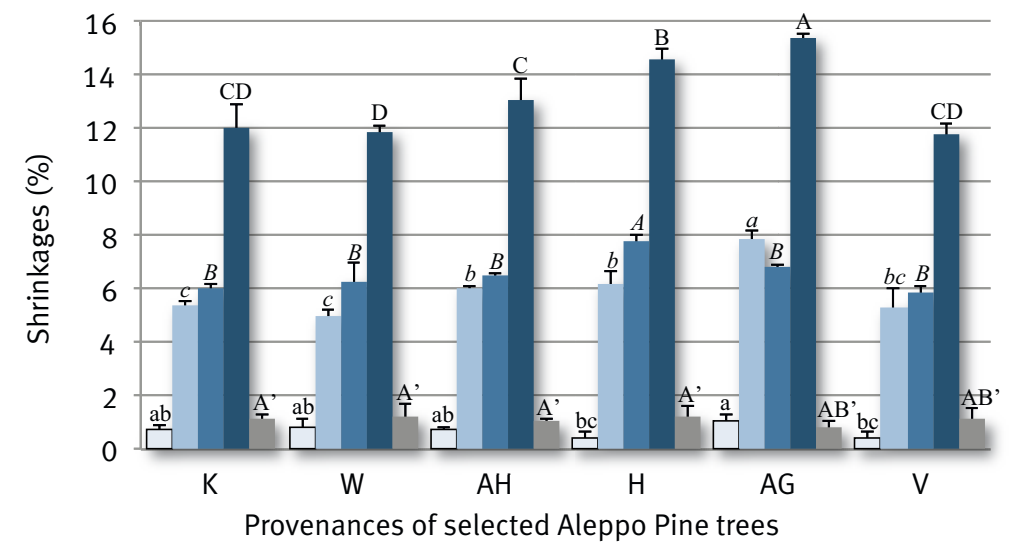

ㄴongitudinal shrinkage ( $\beta 1)$

Radial shrinkage ( $\beta r)$

- Tangential shrinkage $(\beta t)$

- Volumetric shrinkage $(\beta \mathrm{v})$

$=\operatorname{TARS}(\beta \mathrm{t} / \beta \mathrm{r})$

Figure 4.

Average and covariance values of shrinkages in different orientation of Aleppo Pine woods according to their source regions.

Provenances: Jbel Abderrahmane (K), Sodga (W), M'guila (AH), Sakiet (H), Selloum (AG), Dernaia (V).

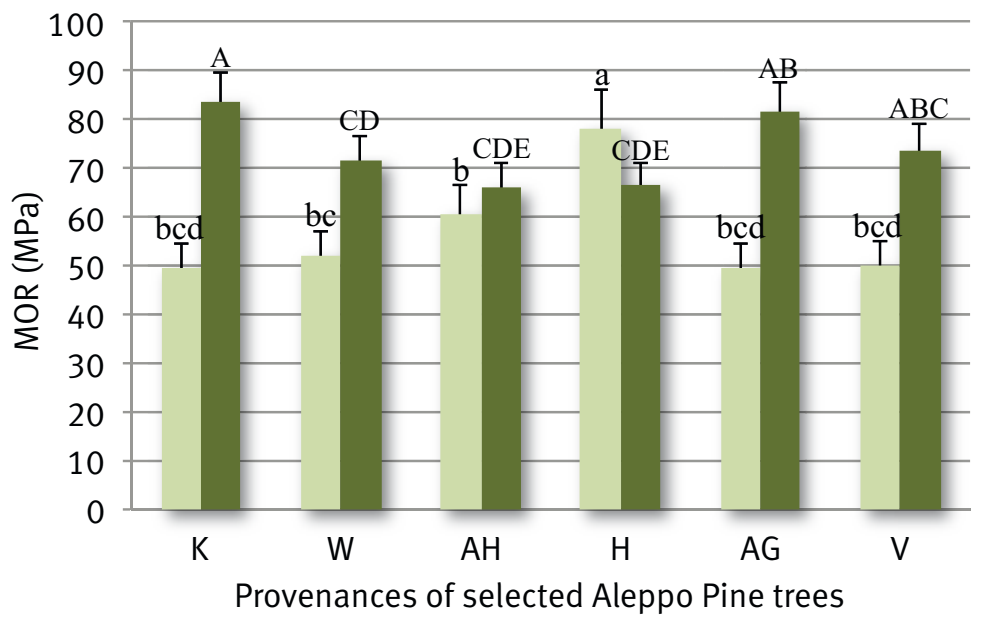

Bending strength (MOR)

Compression strength

(MOR)

Figure 5.

Average and class* values of Modulus of Rupture (MOR) in bending and compression strength of Aleppo Pine woods according to their source regions. Provenances: Jbel Abderrahmane (K), Sodga (W), M'guila (AH), Sakiet (H), Selloum (AG), Dernaia (V).

* According to Polge (1978): Bending classes: from 50 to $75 \mathrm{MPa}$, low; from 75 to $110 \mathrm{MPa}$, medium; from 110 to $140 \mathrm{MPa}$, high.

Compression classes: from 30 to $40 \mathrm{MPa}$, low; from 40 to $55 \mathrm{MPa}$, medium; from 55 to 75 , high.

any significant effect of the tree growth area and stand density on these wood densities (figure 3). Even if, the higher wood basic density $\left(D_{b}=0.53\right)$ is those of Aleppo Pine wood from Sakiet area with the higher tree population density, the lower basic densities corresponds to the Aleppo Pine wood density from Jbel Abderrahmane $\left(D_{b}=0.48\right)$ and Dernaia $\left(D_{b}=0.47\right)$ areas with the lower stand density. The correlation coefficient (table $\mathrm{VI}$ ) is not efficient enough to link basic density with stand density. The results obtained through this study are in agreement with those from Dhaman (1974, 1986) who found that Tunisian Aleppo Pine wood has an infra-density ranged from 500 to $570 \mathrm{~kg} / \mathrm{m}^{3}$.

\section{Shrinkages}

According to the shrinkage analyses, the results illustrated in figure 4 , show the tangential $(\beta \mathrm{t})$, radial $(\beta r)$ and volumetric $(\beta v)$ shrinkage values of Aleppo Pine woods are very similar to each other, irrespective of the tree's origin and tree population density.

Higher shrinkage values are $1.1 \%(\beta \mathrm{l}), 6.5 \%(\beta v)$ and $15 \%(\beta v)$ for Aleppo Pine from Selloum, 7.8\% ( $\beta \mathrm{t}$ ) for Pinus halepensis from Sakiet. These various average shrinkage values are $0.71 \%(\beta \mathrm{l}), 6.55 \%(\beta \mathrm{t}), 5.73 \%(\mathrm{Br})$ and $13.06 \%$ $(\beta v)$, respectively. 
Table IV.

Synthesis of the results of growth parameters, tree characteristics and physical properties of the Tunisian Aleppo Pine wood.

\begin{tabular}{|c|c|c|c|c|c|c|c|c|c|c|c|}
\hline Area & & & ee & Den & ties & & Shr & nkages & & Mech & nical \\
\hline $\begin{array}{l}\text { Provenance sites } \\
\text { in Tunisia }\end{array}$ & $\begin{array}{c}\text { Tree } \\
\text { density }\end{array}$ & $\begin{array}{l}\text { Sizer } \\
(\mathrm{m})\end{array}$ & $\begin{array}{l}\text { Diameter } \\
\text { (m) }\end{array}$ & $D_{b}$ & $D_{0}$ & $\boldsymbol{\beta}_{\mathrm{r}}$ & $\boldsymbol{\beta}_{\mathrm{t}}$ & $\boldsymbol{\beta}_{\mathrm{v}}$ & $\beta_{t} / \beta_{r}$ & $\begin{array}{c}\text { MOR } \\
\text { Bending }\end{array}$ & $\begin{array}{l}\text { MOR } \\
\text { Comp. }\end{array}$ \\
\hline Jbel Abderrahmane (K) & $\begin{array}{l}312.50 \\
308.64\end{array}$ & $\begin{array}{c}11 \\
10.5\end{array}$ & $\begin{array}{l}0.16 \\
0.16\end{array}$ & $\begin{array}{l}0.50 \\
0.46\end{array}$ & $\begin{array}{l}0.52 \\
0.47\end{array}$ & $\begin{array}{l}5.35 \\
5.38\end{array}$ & $\begin{array}{l}5.39 \\
6.59\end{array}$ & $\begin{array}{l}12.62 \\
14.44\end{array}$ & $\begin{array}{l}0.43 \\
0.46\end{array}$ & $\begin{array}{l}53.54 \\
44.88\end{array}$ & $\begin{array}{l}80.48 \\
86.47\end{array}$ \\
\hline Sodga (W) & $\begin{array}{l}277.77 \\
297.79\end{array}$ & $\begin{array}{c}10.7 \\
9.5\end{array}$ & $\begin{array}{l}0.16 \\
0.16\end{array}$ & $\begin{array}{l}0.53 \\
0.54\end{array}$ & $\begin{array}{l}0.54 \\
0.48\end{array}$ & $\begin{array}{l}4.71 \\
5.19\end{array}$ & $\begin{array}{l}5.30 \\
7.48\end{array}$ & $\begin{array}{l}11.05 \\
14.07\end{array}$ & $\begin{array}{l}0.48 \\
0.53\end{array}$ & $\begin{array}{l}48.98 \\
56.31\end{array}$ & $\begin{array}{l}69.80 \\
76.00\end{array}$ \\
\hline M'guila (AH) & $\begin{array}{l}151.50 \\
294.11\end{array}$ & $\begin{array}{l}10.5 \\
11.6\end{array}$ & $\begin{array}{l}0.15 \\
0.22\end{array}$ & $\begin{array}{l}0.50 \\
0.51\end{array}$ & $\begin{array}{l}0.52 \\
0.58\end{array}$ & $\begin{array}{l}6.02 \\
6.09\end{array}$ & $\begin{array}{l}6.18 \\
7.16\end{array}$ & $\begin{array}{l}16.29 \\
18.29\end{array}$ & $\begin{array}{l}0.38 \\
0.39\end{array}$ & $\begin{array}{l}36.40 \\
70.98\end{array}$ & $\begin{array}{l}61.79 \\
80.19\end{array}$ \\
\hline Sakiet (H) & $\begin{array}{l}286.36 \\
500.00\end{array}$ & $\begin{array}{l}11.7 \\
11.3\end{array}$ & $\begin{array}{l}0.15 \\
0.19\end{array}$ & $\begin{array}{l}0.56 \\
0.51\end{array}$ & $\begin{array}{l}0.63 \\
0.44\end{array}$ & $\begin{array}{l}6.28 \\
6.07\end{array}$ & $\begin{array}{l}7.49 \\
8.04\end{array}$ & $\begin{array}{l}20.76 \\
22.13\end{array}$ & $\begin{array}{l}0.36 \\
0.36\end{array}$ & $\begin{array}{l}83.26 \\
78.19\end{array}$ & $\begin{array}{l}66.00 \\
67.60\end{array}$ \\
\hline Selloum (AG) & $\begin{array}{l}202.42 \\
151.33\end{array}$ & $\begin{array}{c}10 \\
10.3\end{array}$ & $\begin{array}{c}0.165 \\
0.18\end{array}$ & $\begin{array}{l}0.50 \\
0.51\end{array}$ & $\begin{array}{l}0.53 \\
0.54\end{array}$ & $\begin{array}{l}8.50 \\
7.40\end{array}$ & $\begin{array}{l}7.97 \\
5.39\end{array}$ & $\begin{array}{l}19.43 \\
16.47\end{array}$ & $\begin{array}{l}0.41 \\
0.33\end{array}$ & $\begin{array}{l}28.63 \\
57.44\end{array}$ & $\begin{array}{l}83.53 \\
80.07\end{array}$ \\
\hline Dernaia (V) & $\begin{array}{l}157.13 \\
212.44\end{array}$ & $\begin{array}{c}10 \\
10.2\end{array}$ & $\begin{array}{l}0.15 \\
0.18\end{array}$ & $\begin{array}{l}0.50 \\
0.45\end{array}$ & $\begin{array}{l}0.56 \\
0.56\end{array}$ & $\begin{array}{l}4.58 \\
6.12\end{array}$ & $\begin{array}{l}5.62 \\
6.19\end{array}$ & $\begin{array}{l}13.66 \\
14.40\end{array}$ & $\begin{array}{l}0.41 \\
0.43\end{array}$ & $\begin{array}{l}66.69 \\
44.61\end{array}$ & $\begin{array}{l}73.80 \\
73.80\end{array}$ \\
\hline
\end{tabular}

Table V.

Pearson Correlation matrix and respective P values (significant level at 0.05 ) of all forestry conditions, tree characteristics and physical/mechanical properties of the Northern Tunisian Aleppo Pine wood sampled.

Area

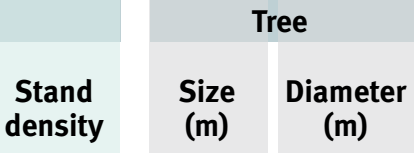

1.00

Stand density

Sizer $(\mathrm{m})$

Diameter (m)

$D_{b}$

$\mathrm{D}$

$\beta_{r}$

$\beta_{\mathrm{t}}$

$\beta_{\mathrm{v}}$

$\beta_{t} / \beta_{r}$

MOR Bending

MOR Comp.
$0.50 \quad 1.00$

0.098

0.33

0.292

0.17

0.599

0.49

0.108

0.21

0.518

0.50

0.101

0.35

0.262

0.11

0.725

0.49

0.06

0.858
Densities

$D_{b} \quad D_{0}$
Shrinkages

$\begin{array}{lllll}\boldsymbol{\beta}_{\mathrm{r}} & \boldsymbol{\beta}_{\mathrm{t}} & \boldsymbol{\beta}_{\mathrm{v}} & \boldsymbol{\beta}_{\mathrm{t}} / \boldsymbol{\beta}_{\mathrm{r}}\end{array}$
Mechanical

properties

MOR MOR Bending Comp. 
Table VI.

Focus on the Correlations between stand density and the other tree characteristics and the physical and mechanical wood properties.

\begin{tabular}{|c|c|c|c|}
\hline Variables & Correlation coefficient of Pearson & $\mathbf{R}^{2}$ & P value \\
\hline Sizer $(m)$ & 0.499 & 0.249 & 0.098 \\
\hline Diameter (m) & 0.332 & 0.110 & 0.292 \\
\hline $\mathrm{D}_{\mathrm{b}}$ & 0.169 & 0.029 & 0.599 \\
\hline $\mathrm{D}_{0}$ & 0.487 & 0.237 & 0.108 \\
\hline$\beta_{\mathrm{r}}^{0}$ & 0.207 & 0.043 & 0.518 \\
\hline$\beta_{t}$ & 0.497 & 0.247 & 0.101 \\
\hline$\beta_{v}$ & 0.352 & 0.124 & 0.262 \\
\hline$\beta_{t} / \beta_{r}$ & 0.114 & 0.013 & 0.725 \\
\hline MOR Bending & 0.490 & 0.240 & 0.105 \\
\hline MOR Comp. & 0.058 & 0.003 & 0.858 \\
\hline
\end{tabular}

properties of Aleppo Pine wood vary widely according to various external factors, including the age of the trees and the growth conditions. In the present study, MOR in bending and in compression strength measurements are respectively ranged from 66.3 to 83.8 $\mathrm{MPa}$ and from 49.4 to $78.2 \mathrm{MPa}$. Northern Tunisian Aleppo Pine supports the comparison with other traditional softwood species as Pinus sylvestris, Abies alba, Pseudotsuga menziesii and Picea abies, both for its mechanical properties and its dimensional stability characteristics (Gérard et al., 2004).

\section{Mechanical properties}

The mechanical test results of each wood sample issued from the six regions are shown in table $V$. Modulus of rupture (MOR) reflects the maximum capacity in bending or in compression and is proportional to the maximum moment borne by a sample. Based on the MOR in bending and in compression strength measurements (figure 5) and the results from statistical analyses using the t-test with Microsoft Excel ${ }^{\mathrm{TM}}$ statistical tool (table $\mathrm{V}$ ), tree growing area and stand density does not have a significant impact on Aleppo Pinewood mechanical properties. The MOR average values in bending and in compression of northern Tunisian woods tested in this study were $56.63 \mathrm{MPa}$ and $73.92 \mathrm{MPa}$, respectively. These results show that the Northern Tunisian Aleppo Pine wood can be classified as having low static bending strength ( $50 \mathrm{MPa}<\mathrm{MOR}<75 \mathrm{MPa}$ ) and high axial compressive strength (55 MPa < MOR < $75 \mathrm{MPa}$ ) (Collardet and Besset, 1998). According to previous studies (Malkh, 2001; Dilem, 1992; Thibaut et al., 1992; Langbour et al., 2008) mechanical
Aleppo Pine wood (from Morocco) was studied for its durability towards both fungi and termites. The tests were performed without accelerated ageing according to the methods described in the EN 350-1 (1994).

\section{Decay resistance}

The mean mass loss on all the Pinus sylvestris reference specimens was $48.23 \%$ for Gloeophyllum trabeum, $38.74 \%$ for Coniophora puteana, and $29.80 \%$ for Poria placenta.

The results about natural durability against fungi of Aleppo Pine wood will be detailed according to each testing fungal species. It must be noticed that only few other durability results about Aleppo Pine wood are available in literature. The results of the biological resistance against Basidiomycetes are given in table VII.

The mass losses of the controls allow the test validation. Aleppo Pine was shown to be slightly durable towards Poria placenta, and non-durable towards both Gloeophyllum trabeum and Coniophora puteana. Considering the

Table VII.

WL (\%) mean values, median values and Durability Class according to decay tests of Moroccan Aleppo Pine, according to XP CEN/TS 15083-1 (2006) (see table III).

\begin{tabular}{|c|c|c|c|c|c|}
\hline \multirow[t]{2}{*}{ Fungi } & \multirow{2}{*}{$\begin{array}{c}\text { Mean Mass Loss }(\%) \\
\text { Virulence controls }(\mathrm{N}=10)\end{array}$} & \multicolumn{3}{|c|}{ Mass loss $(\%)$ - Aleppo Pine samples $(\mathrm{N}=32)$} & \multirow{2}{*}{ Classification (TS 15083-1)* } \\
\hline & & Mean & Median & Standard deviation & \\
\hline $\begin{array}{l}\text { Gloeophyllum } \\
\text { trabeum }\end{array}$ & 48.23 & 47.39 & 47.39 & 4.61 & $\begin{array}{l}\text { Durability class } 5 \\
\text { "Non durable" }\end{array}$ \\
\hline $\begin{array}{l}\text { Poria } \\
\text { placenta }\end{array}$ & 29.80 & 21.89 & 22.05 & 5.54 & $\begin{array}{l}\text { Durability class } 4 \\
\text { "Slightly durable" }\end{array}$ \\
\hline $\begin{array}{l}\text { Coniophora } \\
\text { puteana }\end{array}$ & 38.74 & 35.22 & 34.65 & 4.52 & $\begin{array}{l}\text { Durability class } 5 \\
\text { "Non durable" }\end{array}$ \\
\hline
\end{tabular}


little difference between the mean and median mass losses for each test fungus, natural durability of tested Moroccan Aleppo Pine against brown rot fungi does not appear to be variable. These natural durability results of Moroccan Aleppo Pine are consistent with previous study (Montibus, 2015), and results from Elaieb et al. $(2014,2015)$ concerning decay resistance of the Tunisian Aleppo Pine wood. So, it results that Aleppo Pine wood species is globally classified as a slightly or non-durable wood (corresponding to a durability class 4 or 5). According to the EN 460 standard (1994), Aleppo Pine wood can be used in use class 1 and in use class 2 provided that the material undergoes a preservation treatment depending on the material utilization conditions.

\section{Termite resistance}

The termite resistance test is valid as the Pinus sylvestris sapwood controls presented a strong attack (visual rating 4) and above $50 \%$ of the termite workers remainded alive at the end of the test. After 8 weeks of Aleppo Pine samples exposure to termites, the median survival rate of the insects was $42.4 \%$ and the termite attack had got through all samples causing tunneling and heavy degradations. All Aleppo Pine samples had a visual rating of 4 , which corresponds to a strong degradation. In other words, Moroccan Aleppo Pine used in this study was classified sensible to termites.

\section{Discussion}

\section{Effects of the Aleppo Pine tree provenance on physical and mechanical wood properties}

Zobel and Van Buijtenen (1989) suggest that large structure variations are produced by changes in climate, site and management characteristics, due to the influence of these extrinsic factors on various activities. The results from table $V$ indicate that there are no significant differences among wood coming from different provenances (with various locations, soil characteristics and pluviometry levels) in terms of wood densities. Concerning the Aleppo Pine wood shrinkages properties, it results that the wood coming from Sakiet $(\mathrm{H})$ and Selloum $(A G)$ areas have significant higher radial $\left(\beta_{\mathrm{r}}\right)$, tangential $\left(\beta_{\mathrm{t}}\right)$ and volumetric $\left(\beta_{\mathrm{v}}\right)$ shrinkages values than the woods coming from the four other provenances. This difference could be explained by the high level of pluviometry and the soil composition of the Sakiet $(\mathrm{H})$ and Selloum (AG) areas. Results show that Aleppo Pine wood from Sakiet $(H)$ has a significant higher Bending strength than the other woods, which could be explained by the high values of tree size and wood basic density. In fact, our results from the second statistical analysis, illustrated in table $\mathrm{V}$, show that tree size and wood basic density are moderately correlated with the wood bending strength properties. The variability of the compression MOR according to the tree provenance is less significant than those of Bending MOR. Similar results were found recently by a study focused on the Tunisian Pinus pinea wood characterization (Elaieb et al., 2015).

\section{Correlations between forestry conditions, tree characteristics and physical/mechanical Aleppo Pine wood properties}

Results from table $V$ show that the most positive correlations were found between wood stand density and bending strength (MOR Bend) [correlation coefficient of $0.49, \mathrm{P}$ value $=0.105]$, and between basic density $(\mathrm{Db})$ and bending strength (MOR Bend) [correlation coefficient of 0.52 , $P$ value $=0.082$ ]. These results support previous studies (Zhang and Zhong, 1997; Betkas et al., 2002; Heräjärvi, 2004).

According to table VI, Aleppo Pine stand density is moderately correlated with the tree size (correlation coefficient of 0.499 , $P$ value $=0.098$ ). Although it was weak, tree diameter had a positive correlation with wood bending and compression MOR. Wood basic density seems also to have slight positive correlation with stand density and moderate positive correlation with bending MOR. Concerning wood shrinkages properties, it appears that stand density have moderate positive correlations with tangential and volumetric shrinkages and slight positive correlation with the Transverse Anisotropic Ratio for Shrinkage $\left(\beta_{t} / \beta_{r}\right)$. No other obvious correlations between stand densities, tree diameters, tree heights and physical and mechanical properties have been found through this study.

\section{Aleppo Pine wood classification}

According to Campredon (1967), Tunisian Aleppo Pine timbers tested in this study can be classified as a light heavy weight wood $\left(0.5<D_{m 12}<0.6\right)$, medium wood volumetric $\left(10 \%<\beta_{v}<15 \%\right)$ and medium wood linear $\left(6.5 \%<\beta_{\mathrm{t}}<10 \%\right.$; $\left.3.75 \%<\beta_{r}<6.5 \%\right)$ shrinkages. In addition, Aleppo Pine wood generally seems to have a lower Transverse Anisotropy Ratio for Shrinkage $\left(\beta_{t} / \beta_{r}=1.15\right)$ than those of other softwood species (El Jazouli et al., 2000; Azzouzi, 1995; Elaieb et al., 2015) such as Pinus pinea (1.53), Pinus pinaster (2), Pinus sylvestris (1.7) or Pseudotsuga menziesii (1.7), making it a wood relatively easy to dry before being used (Thibaut, 1992).

Relative to standard on wood durability, Moroccan Aleppo Pine heartwood appears to be classified as sensible against termites, non-durable against Coniophora puteana and Gloeophyllum trabeum basidiomycete attacks and slightly durable against Poria placenta basidiomycete attack.

\section{Conclusion}

As for most Pine species, Moroccan Aleppo Pine showed a low durability: "not durable" towards both Coniophora puteana and Gloeophyllum trabeum, "slightly durable" toward Poria placenta attacks, and was classified "sensible" against termites. However, Aleppo Pine durability does not appear to vary depending on the provenance.

The physical and mechanical features have shown a wood characterized by rather good values, highlighting that the wood is very stable and that the structural efficiency of the Tunisian Aleppo Pine wood is high, compared to that of the most utilized softwood species for structural purposes. 
From first trials the Aleppo Pine wood from Maghreb area seems to be suitable for packing and structures, even if its heartwood low durability and dimensional stability could allow, in case of high quality wood undergoing a preservation process, the use for window frames.

The species shows a good ecological adaptability and the quality of the standing trees in artificial plantation seems to be better compared to other softwoods at present used in Mediterranean countries, such as Pinus pinea, Pinus radiata and Pinus insignis, even if no cultural operations, like thinning or pruning were made.

Further studies on the heartwood percentage in mature trees, on the impregnability of the sapwood and on durability for above ground in use situation improve the knowledge of that wood and suggest larger utilizations of Aleppo Pine.

In conclusion, all qualification testing showed that the Maghreb Aleppo Pine wood is softwood with good technological value. However, the high rate of resin that it contains and its large numbers of knots are two unfavorable factors for an efficient sawing and they do that the Aleppo Pine wood remains very limited used as wood material. It could be interesting now to think about new forestry methods to limit the number of nodes and improve the tree rectitude.

\section{Aknowledgments}

The authors gratefully thank the National Institute of Agricultural Engineering Research, Water and Forest (INRGREF) and the General Direction of Forestry (DGF).

\section{References}

Aafi A., 2007. Study of the floral diversity of the cork oak forest ecosystem of Mamora. PhD Thesis [in French]. Foresterie, Institut Agronomique et Vétérinaire Hassan II, Morocco.

Azzouzi K., 1995. Propriétés technologiques du bois du cèdre de l'Atlas; Influence de la sylviculture pratiquée sur plusieurs types de substrats. Thèse de doctorat de l'ENGREF, Montpellier, France ,190 p.

Bektas I., Guler C., Basturk M. A., 2002. Principal mechanical properties of eastern beech wood (Fagus orientalis) naturally grown in Andir in north eastern Mediterranean region of Turkey. Turkish Agriculture and Forestry, 26: 147-154.

Belghazi B., Ezzahiri M., Romane F., 2000. La productivité des peuplements naturels de pin d'Alep dans la forêt de Tamga (Haut Atlas marocain). Forêt Méditerranéenne, 26, 4 : 521- 529.

Boulli A., Baaziz M., M’Hirit O., 2001. Polymorphism of natural populations of Pinus halepensis Mill. in Morocco as revealed by morphological characters. Euphytica 119: 309-316.

Campredon J., 1967. Teaching of Wood Technology. I.G.R.E.F., $12 \mathrm{p}$.
Candelier K., Hannouz S., Elaieb M., Collet R., Dumarçay S., Pétrissans A., Gérardin P., Pétrissans M., 2015. Utilization of temperature kinetics as a method to predict treatment intensity and corresponding treated wood quality: durability and mechanical properties of thermally modified wood. Maderas Ciencia y Tecnología, 17 (2): 253-262.

Crammond P. C., 1999. An Investigation of Aleppo Pine for Low Rainfall Farm Forestry. Rural Industries Research and Development Corporation No 99/016, 50 pages. ISSN 1440-6845.

Collardet J., Besset J., 1988. Les bois commerciaux et leurs utilisations. Bois résineux (Conifères) - Tome 1 . Institut technologique forêt cellulose bois ameublement, Direction du Centre Technique du Bois et de l'Ameublement, Champssur-Marne, France, 277 p.

Correal-Mòdo E., Vilches Casals M., 2012. Properties of clear wood and structural timber of Pinus halepensis from northeastern spain. Proceedings of WCTE 2012 (Vol.5), Auckland, New Zealand, 251-254.

DGF (Direction Générale des Forêts), 2010. Résultats du deuxième inventaire forestier et pastoral national. Inventaire des forêts par télédétection. Ministère de l'Agriculture, Tunis, $180 \mathrm{p}$.

Dhaman M., 1974. Pinus halepensis: its technological characteristics and utilizations. Bulletin d'Information, Institut National de Recherches Forestières, Tunisie, 17: 9-12.

Dhaman M., 1986. Les produits de pin d'Alep en Tunisie. CIHEAM, Options Méditerranéennes, 1 : 157-161.

Dilem A., 1992. Contribution to the study of determinism of some basic properties of the Aleppo Pine (Pinus halepensis Mill.). PhD Thesis [In French], Institut National Polytechnique de Lorraine, Nancy, France, 133 p.

Elaieb M., Candelier K., Dumarçay S., Pétrissans A., Gérardin P., Pétrissans M. 2014. Chemical modification during heat treatment of Tunisian soft wood species. International Conference "Recent Advances in the Field of TH and THM Wood Treatment", May 19-21, 2014, Skelleftea, Sweden.

Elaieb M. T., Candelier K., Dumarçay S., Pétrissans A., Gérardin P., Pétrissans M., 2015. Heat treatment of Tunisian soft wood species: effect on the durability, chemical modifications and mechanical properties. Maderas Ciencia y Tecnología, 17 (4): 699-710.

Elaieb M. T., Khaldi A., Candelier K., 2015. Impact of location and forestry conditions on some physical and mechanical properties of northern Tunisian Pinus pinea L. wood. Bois et Forêts des Tropiques, 324 (2): 65-74. http://bft.cirad.fr/cd/ BFT 324 65-74.pdf

El Abid A., 1981. Aptitudes technico-économiques du Pin d'Alep et du Pin Maritime issus des reboisements marocains à produire du bois de mine. Annales de la Recherche Forestière au Maroc, 21, 1981-1401.

El Jazouli A., Fechtal M., Hachmi M., Sesbou A., 2000. Caractéristiques technologiques du bois du Pin maritime (Pinus pinaster var. atlantica) des reboisements de la Maâmora occidentale. Annales de la Recherche Forestière au Maroc, $33: 115-126$. 
EN 118, 2005. Wood preservatives. Determination of preventive action against Reticulitermes species (European termites) (laboratory method). BSI Standards Publication, 22 p. EN 350, 2016. Durability of wood and wood-based products - Testing and classification of the durability to biological agents of wood and wood-based materials. BSI Standards Publication, $72 \mathrm{p}$.

EN 350-1, 1994. Durability of wood and wood-based products. Natural durability of solid wood. Part 1: Guide to the principles of testing and classification of the natural durability of wood. BSI Standards Publication, $16 \mathrm{p}$.

EN 408, 2003. Standard - Timber structures. Structural timber and glued laminated timber. Determination of some physical and mechanical properties, $42 \mathrm{p}$.

EN 460, 1994. Durability of wood and wood-based products. Natural durability of solid wood. Guide of the durability requirements for wood to be used in hazard classes. BSI Standards Publication.

EUFORGEN, 2009. Distribution map of Aleppo Pine (Pinus halepensis). EUFORGEN 2009. www.euforgen.org

Garchi S., Ben Mansoura A., 1999. Influence de l'ombrage sur l'accroissement du pin d'Alep à Jbel Mansour. Les Annales de l'INRGREF, $3:$ 89-102.

Gracia C., Ibàñez J. J., Burriel J. A., Mata T., Vayreda J., 2004. Inventari Ecològic i Forestal de Catalunya. CREAF, Bellaterra.

Gérard J., 2004. Caractérisation technologique et valorisation en bois d'œuvre du Pin d'Alep (Pinus halepensis) de la région Provence-Alpes-Côte d'Azur. Technologie du bois et marchés, Programme du Groupe Pin d'Alep (GPA), 28 p.

Haddad A., Lachenal D., Marechal A., Kaid-Harche M., Janin G., 2006. Caractéristiques papetières de la pâte de bois de thuya de Berbérie (Algérie) (Tetraclinis articulata Vahl) obtenue par un procédé soude-anthraquinone. Annals of Forest Science, 63 : 493-498.

Haddad A., Lachenal D., Marechal A., Janin G., Labiod M., 2009. Delignification of Aleppo Pine wood (Pinus halepensis Mill.) by soda-anthraquinone process: pulp and paper characteristics. Cellulose Chemistry and Technology, 43 (7-8): 287-294.

Haygreen J. G., Bowyer J. L., 1996. Forest Products and Wood Science 3. Edition lowa State University Press, USA.

Herajarvi H., 2004. Static bending properties of Finnish birch wood. Wood Science and Technology, 37: 523-530. DOI: 10.1007/s00226-003-0209-1.

ISO 4469, 1981. Wood. Determination of radial and tangential shrinkage. International Organization for Standardization, $2 \mathrm{p}$.

ISO 4471, 1982. Wood. Sampling sample trees and logs for determination of physical and mechanical properties of wood in homogeneous stands. International Organization for Standardization, $7 \mathrm{p}$.

ISO 13061-2, 2014. Physical and mechanical properties of wood - Test methods for small clear specimens - Part 2: Determination of density for physical and mechanical tests. International Organization for Standardization, 5 p.

Khouja M. L., Sghaier T., Nouri M., André P., 2000. Variabilité morphométrique chez le pin d'Alep (Pinus halepensis Mill.) et perspectives d'amélioration génétique. Les Annales de I'INRGREF, 54 : 78-118.
Khouja M. L., 2003. Étude de la diversité et de la variabilité génétique de 7 espèces forestières de première importance (Pin d'Alep, Pin brutia, Pin pignon, Pin noir, Chêne liège et Cyprès toujours vert). Projet fédérateur : Écologie, sélections d'espèces et reboisement. Rapport final, 1999-2003, 96 p.

Langbour P., Gérard J., Guibal D., Mahlani K., 2011. Caractérisation technologique et valorisation en bois d'œuvre du pin d'Alep de la région Provence-Alpes-Côte d'Azur. Forêt Méditerranéenne, 32 (3) : 263-270.

Malkh B., 2001. Evolution of morphological descriptors and wood properties based on growth parameters of Pinus halepensis Mill. and Pinus brutia Ten.: Comparative study on a tree panel of 21 year old. PhD Thesis [In French]. ENGREF, Montpellier, France.

Mitsopopoulos I. D., Dimitrikopopoulos A. P., 2007. Canopy fuel characteristics and potential crown fire behavior in Aleppo Pine (Pinus halepensis Mill.) forests. Annals of Forest Science, 64: 287-299.

Montibus M., 2015. Détermination de la durabilité et de l'imprégnabilité du Pin d'Alep. FCBA Info, décembre 2015, 45, $7 \mathrm{p}$.

Oger R., Leclercq A., 1977. L'échantillonnage appliqué à la détermination des propriétés physiques et mécaniques du bois. Bulletin de la Recherche Agronomique de Gembloux, 12 (4) : 331-338.

Polge H., 1992. Le bois de pin d'Alep. Forêt méditerranéenne, 13 (3) : 234-237.

Quiquandon, 1966. Étude du bois de pin d'Alep de Tunisie. Publication CTB.

Ricard C., Oliva T., 1995. Valorisation du bois de pin d'Alep Étude Bibliographique. École Nationale des Arts et Métiers, $65 \mathrm{p}$.

Sghaier T., Khouja M. L., 2009. Comportement des provenances de pin d'Alep (Pinus halepensis Mill.) dans le semiaride Tunisien. Annales de l'INRGREF, 13 : 89-106.

Snane M. H., Mechergui M., Hamza E., 1992. Dynamique de la croissance juvénile du pin d'Alep (Pinus halepensis) sous deux techniques de reboisement dans la zone subhumide du Cap-Bon tunisien. Forêt Méditerranéenne, 13 (3) : 262-267.

Thibaut B., Loup C., Chanson B., Dilem A., 1992. La valorisation du pin d'Alep (Pinus halepensis Mill) en zone méditerranéenne française 1992. Forêt méditerranéenne, 13 (3) : 226-233.

Tischler K., 1971. Les propriétés mécaniques et physiques du bois de Pin d'Alep. Publication spéciale Institut Volcani, Département de la recherche forestière.

XP CEN/TS 15083-1, 2006. Durability of wood and woodbased products - Determination of the natural durability of solid wood against wood destroying fungi - Test methods Part 1: Basidiomycetes. AFNOR.

Zhang S. Y., Zhong Y., 1990. Effect of growth rate on specific gravity of East-Liaoning oak (Quercus liaotungensis) wood. Canadian Journal of Forest Research, 21: 255 -260.

Zobel B. J., Van Buijtenen J. P., 1989. Wood variation - its causes and control. Springer Verlag, Berlin. 